KURCHII B.A.

Irpin Economic College,

Ukraine, 08200, Irpin, Gagarina str., 9, e-mail: kurchii@ukr.net, (095) 496-92-88

\title{
THE ROLE OF BIOLOGICALLY ACTIVE SUBSTANCES AND SHORT AT-FRAGMENTS OF NUCLEIC ACIDS IN THE GENETIC TRANSCRIPTION PROCESS
}

The characteristic chemical fragments named as functional reactive groups (or descriptors) in the molecules of biologically active substances (BASs) are described. These fragments are characterized by the presence of an active hydrogen atom or unsaturated function. It is concluded that BASs are essential factors working in concert with gene keys and gene locks to starts transcription. The gene keys are nucleic acids but not proteins. It is postulated that cell membrane can serve as depot for gene keys at the beginning of oxidative stress. During the recession phase of oxidative stress new gene keys are synthesized for new transcription acts.
Keywords: BASs, descriptors, gene keys, gene locks, transcription.

The presence of functionally active groups (or descriptors) in biologically active substances (bioregulators, BASs) is mandatory for the manifestation of their in vivo biological activity. The most typical descriptors of BASs are presented in Fig. 1 and $2[1-3]$.

The substances given as drugs or pesticides that are inactive should be activated in vivo. Formation of active metabolites of BASs, also called biotransformation, may occur by the following ways:

1) Radical addition reactions to aryls (BASs): $\mathrm{Ar}+\mathrm{R}_{1} \longrightarrow \mathrm{ArR}_{1}$

2) Abstraction of the hydrogen atom from BASs: $\mathrm{RH}+\mathrm{R}_{1} \longrightarrow \mathrm{R}_{1} \mathrm{H}+\mathrm{R}^{\cdot}$

3) Free radical addition reactions to the unsaturated function of BASs:<smiles>[R1]C[CH+]C(C)C(C)C([Z1])C</smiles>

Thereby, the inactive BASs require in vivo transformation by endogenous free radicals or enzymes into free radicals. BASs in free radical state can react with essential cellular constituents such as lipids, DNA, RNA, proteins etc. Hence, in vivo activated BAS (the free radical of BAS) can act as initiator $\left(\mathrm{In}^{\circ}\right)$ of free radical chain reactions in the cells. Polyunsaturated fatty acids (LH) presented in the cellular membranes can be easily oxidized. The membrane destruction will be result of this action. I proposed that the transcription process is carried out with the participation of gene keys (primer analogs in PCR) which can be preliminary synthesized and stored within the cell membranes that serve them as depot [3] and can be liberated from membranes under oxidative stress in the cells. Membrane destruction results in the gene key liberation from the cell membranes into the cytoplasm and then it can move to the nucleus (Fig. 3). This scenario may be characteristic for the onset of oxidative stress caused by free radicals of BASs. New gene keys are synthesized at genes for new transcription acts during the recession phase of oxidative stress.

In this paper, I do not consider the currently known mechanisms for synthesizing RNA on DNA template. Only one stage of the RNA synthesis process is described here: recognition of the required gene (or the cluster of genes) from which RNA will be synthesized. RNA synthesis requires single-stranded DNA. But the gene consists of double-stranded DNA on which RNA synthesis is unknown. In order to start the transcription process RNA polymerase must find the necessary gene. The gene key assists RNA polymerase in selection the appropriate gene lock at the gene promoter $[3,4-6]$.

\footnotetext{
${ }^{\circ}$ KURCHII B.A.
} 


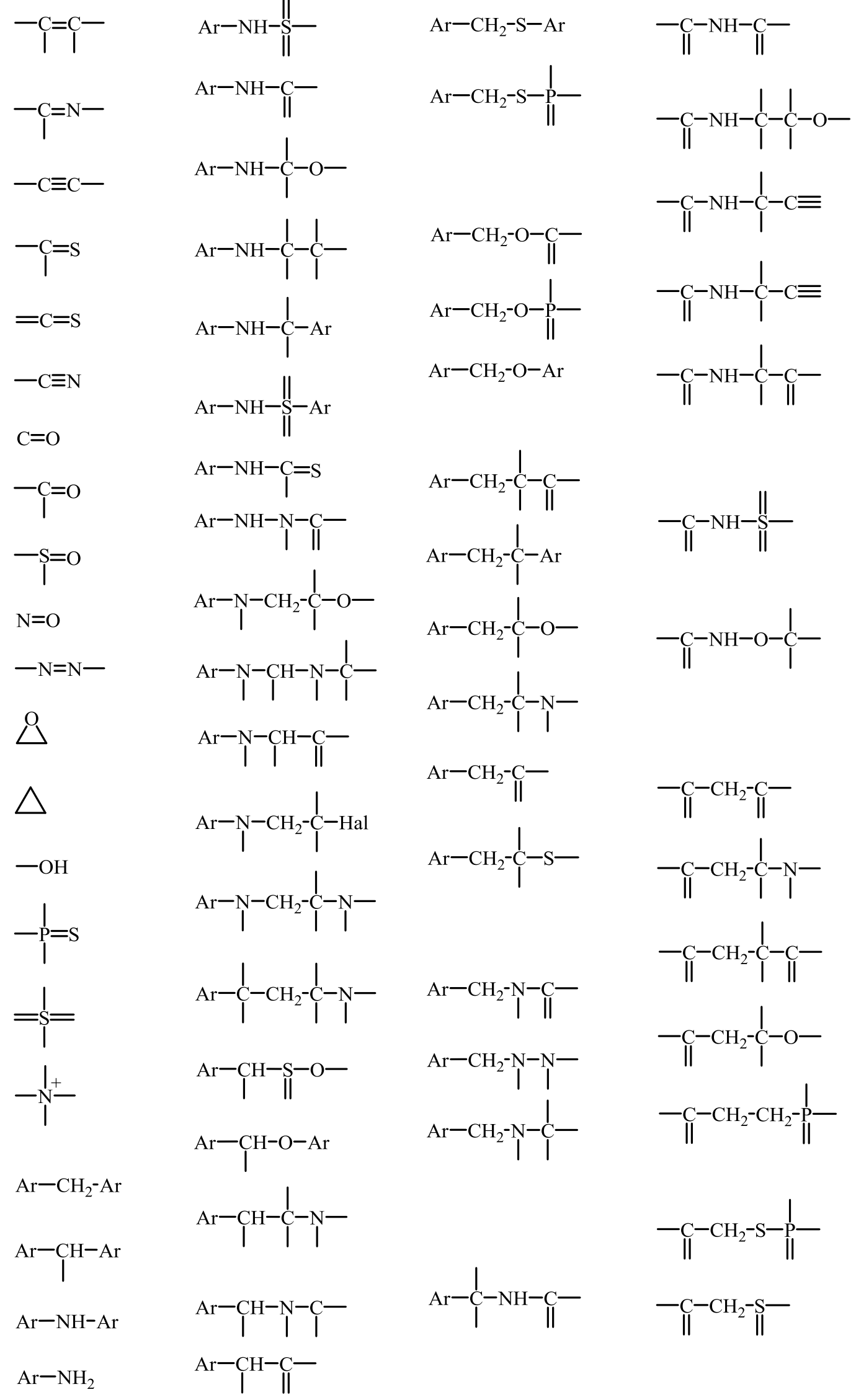

Fig. 1. Functional reactive groups (descriptors) of biologically active substances. 


$$
\underset{\|}{-\mathrm{C}-\mathrm{CH}_{2}-\mathrm{N}-\mathrm{C}-\mathrm{CH}_{2}-\mathrm{N}-\mathrm{Ar}_{\|}^{\mathrm{C}}-\mathrm{O}-\mathrm{CH}_{2}-\mathrm{C}-\mathrm{O}-\mathrm{O}-\mathrm{CH}_{2}-\mathrm{O}-\mathrm{Ar}}
$$

$\underset{\|}{\mathrm{C}-\mathrm{CH}}-\mathrm{O}-\mathrm{C}-$<smiles>C=C(C)C(C)N(C)C(C)C(=C)C</smiles>$$
\mathrm{Ar}-\mathrm{O}-\mathrm{CH}_{2}-\stackrel{\mathrm{C}}{\mathrm{I}}-\mathrm{N}-
$$$$
-\underset{l}{\mathrm{C}}-\mathrm{CH}-\mathrm{C}-
$$<smiles>C=C(C)C(C)C(C)(C)N(C)C</smiles>

$$
\mathrm{Ar}-\mathrm{S}-\mathrm{CH}_{2}-\mathrm{S}-\mathrm{P}=
$$$$
-\stackrel{\mathrm{l}}{-\mathrm{l}}-\mathrm{CH}^{-}-\mathrm{C}-\mathrm{N}-
$$<smiles>C=C(C)C(C)(C)CC(C)(C)C(=C)C</smiles>

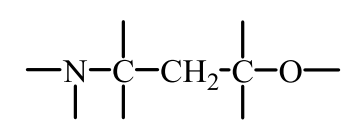<smiles>C=C(C)CC(C)(C)C(=C)C</smiles><smiles>CN(C)C(C)(C)COC(C)(C)C</smiles>

$-\underset{\mathrm{C}}{\stackrel{\mathrm{C}}{\mathrm{C}}-\mathrm{CH}_{2}-\mathrm{C}-\mathrm{I}} \stackrel{\mid}{\mid}$

$$
-\mathrm{l}-\mathrm{l}-\mathrm{CH}^{-} \stackrel{\mathrm{C}}{\mathrm{C}-\mathrm{Hal}}
$$<smiles>C=C(C)C(C)(C)C(C)C(C)(C)N(C)C</smiles>

$-\mathrm{Cl}^{\mathrm{C}}-\mathrm{N}-\mathrm{C}-\mathrm{C}-\mathrm{C}-$<smiles>CC(C)C(C)(C)[Hg]C(C)(C)C</smiles><smiles>C=C(C)N(C)CC(C)(C)N(C)C</smiles><smiles>C=C(C)N(C)CN(C)C(C)(C)C</smiles>

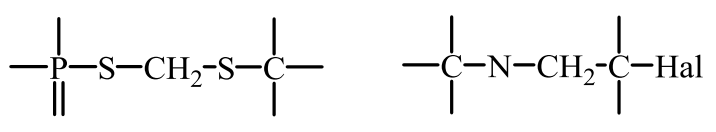

$\stackrel{\text { II }}{\mathrm{P}}-\mathrm{S}-\mathrm{CH}_{2}-\mathrm{S}-\stackrel{\mathrm{C}}{\mathrm{C}}-\stackrel{\mathrm{l}}{\mathrm{C}}-\mathrm{N}-\mathrm{CH}_{2}-\stackrel{\mathrm{C}}{\mid}-\mathrm{O}-$<smiles>C=P(C)(C)SCC(C)(C)N(C)C</smiles><smiles>CC(C)(C)CNC(C)(C)[AlH2]</smiles><smiles>C=C(C)CSP(=C)(C)C</smiles><smiles>CC(C)(C)CSC(C)(C)C</smiles>

$\underset{\|}{\mathrm{P}}-\mathrm{S}^{-}-\mathrm{CH}_{2}-\mathrm{S}-$

$-\mathrm{O}-\mathrm{CH}_{2}-\mathrm{CH}-\mathrm{CH}_{2}-\mathrm{O}-$

$-\mathrm{S}-\mathrm{N}-\mathrm{CH}^{2}-\mathrm{N}-\mathrm{S}-$

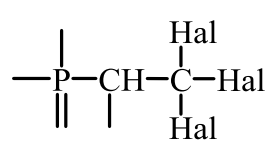

$-{ }_{\mathrm{S}}-\mathrm{C}_{1}^{\mathrm{C}}-\stackrel{\mathrm{C}}{\mathrm{C}}-\mathrm{S}-$

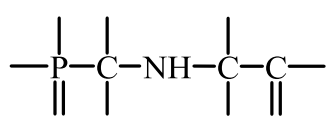<smiles>C=C(C)C(C)(C)C(C)OC(C)(C)C</smiles>

$-\underset{\|}{\mathrm{C}}-\mathrm{O}-\mathrm{CH}_{2} \stackrel{\text { ! }}{\mid}-\mathrm{C}-$

$\underset{\mathrm{P}}{\mathrm{P}}-\stackrel{\mathrm{O}}{\stackrel{\mathrm{C}}{\mathrm{C}}-\mathrm{H}}$

$-\stackrel{\mathrm{C}}{\mathrm{I}}-\mathrm{O}-\mathrm{CH}_{2}-\mathrm{C}-\mathrm{C}$

$\stackrel{\mathrm{P}}{\mathrm{I}} \mathrm{O} \longrightarrow$

$-\underset{\|}{\mathrm{C}}-\mathrm{O}-\mathrm{CH}_{2}-\mathrm{C}-$<smiles>C=P(C)(C)OC(C(C)(C)C)C(C)(C)C</smiles>

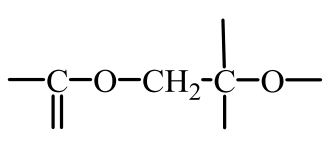

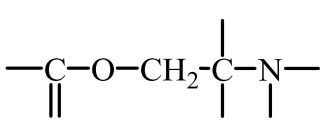

$-\underset{\mathrm{P}}{\mathrm{P}}-\mathrm{O}-\mathrm{CH}-\mathrm{C}\left(\mathrm{CH}_{3}\right)_{3}$

${ }_{\mathrm{C}}^{\mathrm{C}-\mathrm{O}-\mathrm{CH}_{2}-\mathrm{C}-\mathrm{NH}-\mathrm{C}_{\|}^{+}-\mathrm{C}-}$

$-\stackrel{1}{P}=S$

$-\mathrm{l}-$

$-\stackrel{1}{P}=0$

Fig. 2. Functional reactive groups (descriptors) of biologically active substances. 


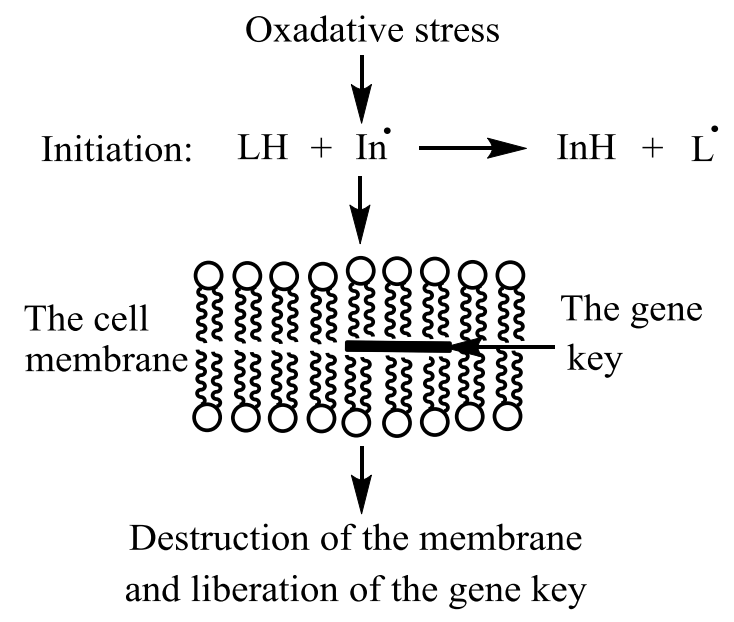

Fig. 3. Scenario of the gene key liberation from the cell membrane.

Gene promoters are characterized by the presence of nucleotide fragments such as TATA box PLM and ТАТАД-PLM motifs [7], CATGCATG motif [8], C-box (ATGACGTCAT) and Gbox (GACACGTGTC) [9], Pribnow box (consensus sequence TAATAT) [10]. These structures are disposed at both ends of the DNA strand.

The gene key that contains TA (or TATA box) nucleotide pairs is presented in vivo by singlestranded DNA or RNA (which must contain adenine nucleotides). The TA nucleotide pairs from the gene key can form a hydrogen bond with one of the DNA strands. The bond is formed between $\mathrm{O}(\mathrm{C} 2)$ of thymine within the gene lock and $\mathrm{H}(\mathrm{C} 6)$ of adenine within the gene key (Fig. 4 and 5).

Analysis of structures in Figures 4 and 5 indicates the presence of all four DNA nucleotides (A-T and $\mathrm{G}-\mathrm{C}$ ). At first glance, nothing special, except for the lack of a hydrogen bond at one of the thymine nucleotide oxygen. But this feature is unique: the hydrogen of the $\mathrm{H}_{2} \mathrm{~N}$-group at $\mathrm{C} 6$ adenine can form a hydrogen bond with oxygen at $\mathrm{C} 4$ or $\mathrm{C} 2$ of thymine. Moreover, only a single-stranded DNA having adenine nucleotide in its structure can form the hydrogen bond with the double-stranded DNA (the gene). Note that neither thymine nor uracil can form the hydrogen bond with the doublestranded DNA due to the already formed the bond at the N1 and C6 adenine atoms. However, uracil of the single-stranded RNA can form the hydrogen bond with the adenine of the single-stranded DNA.
Thus, the most easily hydrogen bonds of the adenine nucleotide (A) can be formed with thymine (T) nucleotides, which must be present in the DNA of the gene in at least two places. The ideally the linear length of the gene key should match the linear length of the gene lock. Accordingly, at least two nucleotides of adenine (A) must be present at the beginning and the end of the gene key.

Theoretically, the gene key can be attached to both $5^{\prime}$ end (Fig. 4) and $3^{\prime}$ end of DNA strands (Fig. 5). It is believed that the $3^{\prime}$ end variant may be preferred [11]. However, if the gene key is needed to separate DNA strands, then its attachment can also take place to the strand with $5^{\prime}$ end of DNA (Fig. 5).

\section{Conclusions}

In conclusion, it should be emphasized that when considering transcription of DNA with the participation of receptors, the role of BASs in the initiation of oxidative processes in the cell membranes should be taken into account. Unfortunately, described in the literature the scenarios of DNA transcription involving protein receptors, the role of BASs in the initiation of oxidative processes in membranes are absent. Moreover, in the described mechanisms of the participation of protein receptors in transcription, the role of BASs is not mentioned at all. The role of BASs and protein receptors in the processes of transcription inhibition and the death of living beings under the influence of large concentrations of BASs is also not mentioned. 


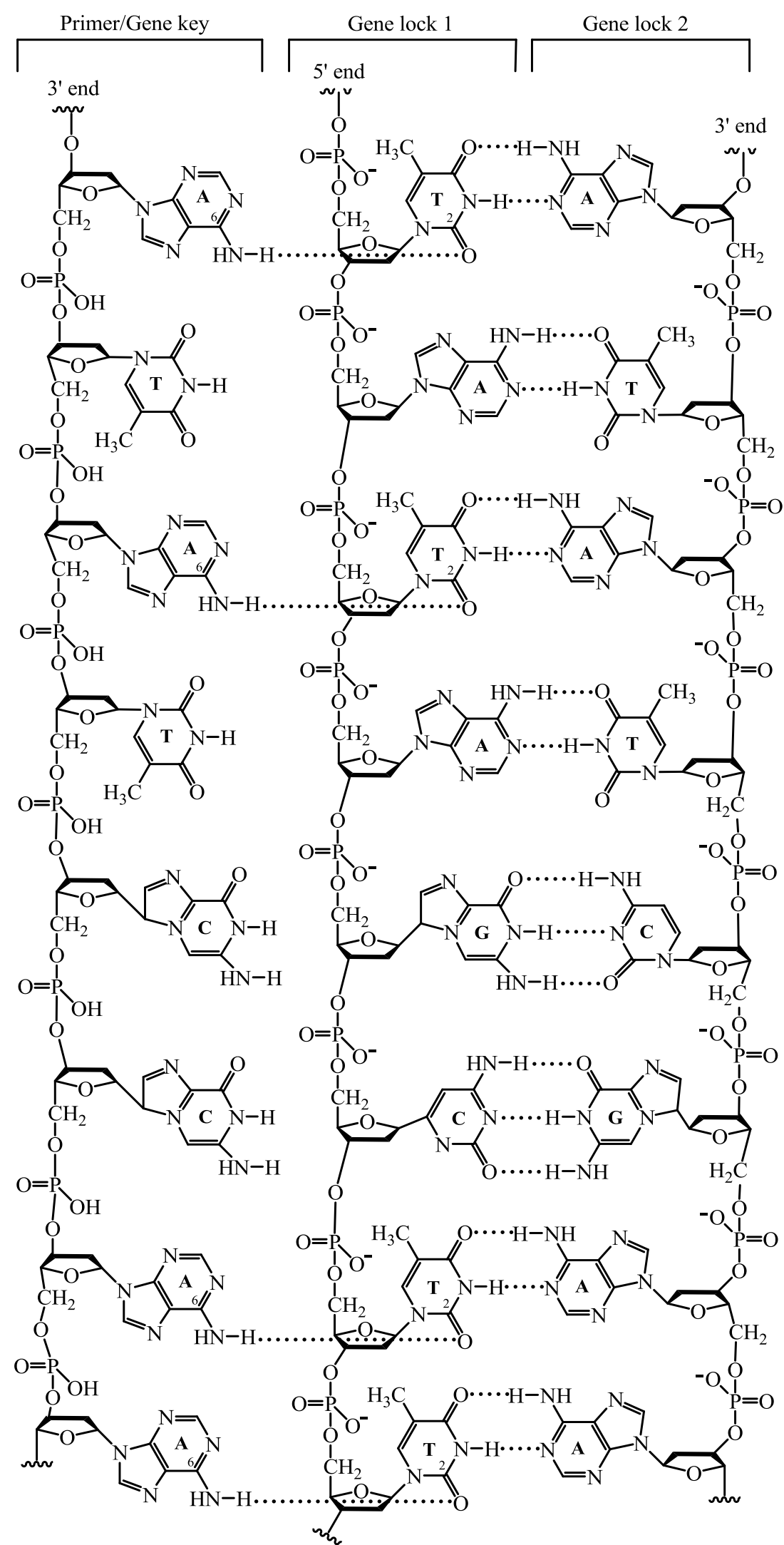

Fig. 4. The formation of hydrogen bonds between T-A base pairs (the gene lock) of the promoter with A base of the gene key (the primer). The gene key works in concert with RNA polymerases and other factors including so colled "transcription factors". As follow-up to this model, thymine nucleotide in the gene key is not necessary in the mechanism of interaction with the gene lock (DNA matrix). 


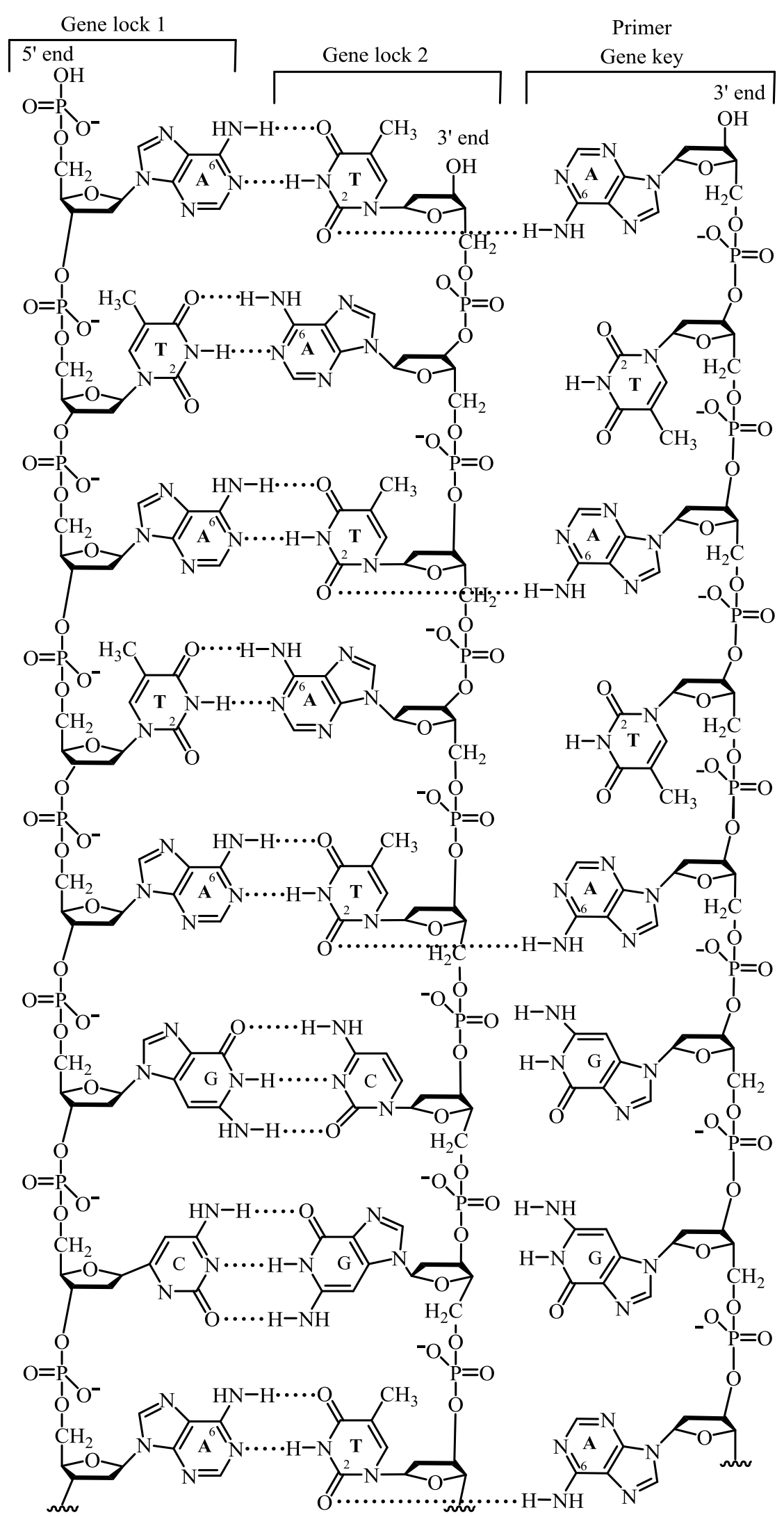

Fig. 5. The formation of hydrogen bonds between T-A base pairs (the gene lock) of the promoter with A base of the gene key (the primer). The gene key works in concert with RNA polymerases and other factors including so colled "transcription factors". As follow-up to this model, thymine nucleotide in the gene key is not necessary in the mechanism of interaction with the gene lock (DNA matrix). 


\section{References}

1. Kurchii B.A. Chemical structure of descriptors with an active hydrogen atom in certain bioregulators. Ukr. Biochem. J. (Kiev). 1996. Vol. 68. P. 3-13.

2. Kurchii B.A. What Regulate the Growth Regulators? Kiev: Logos publisher, 1998. 202 p.

3. Kurchii B.A. What regulate the growth regulators? Second edition. Revised and expanded. Kiev: Logos publisher, 2019. 209 p.

4. Kurchii B.A. Under lock and key: Small DNA-protein complexes can present the gene keys to the gene locks composed from DNA. XXII International Conference on Yeast Genetics \& Molecular Biology (7-12 August, 2005, Bratislava, Slovak Republic). Abstract 15-3, S. 188.

5. Kurchii B.A. Adenine and thymine nucleotides are major players in the structure of a gene lock and a gene key in eukaryotes. Yeast genetics and molecular biology meeting. (Princeton University, Princeton, New Jersey, July 25-30, 2006a). Program and abstracts. Abstract N 352A. P. 175.

6. Kurchii B.A. On the molecular nature of the lock and the key for the eukaryal genes/clusters. Proceeding of IX Ukrainian Biochemical Congress (24-27 October 2006b, Kharkiv, Ukraine). P. 49-50.

7. Bernard V., Brunaud V., Lecharny A. TC-motifs at the TATA-box expected position in plant genes: a novel class of motifs involved in the transcription regulation. BMC Genomics. 2010. Vol. 11. P. 166. URL: http://www.biomedcentral.com/14712164/11/166.

8. Reidt W., Wohlfarth T., Ellerstrom M., Czihal A., Tewes A., Ezcurra I., Rask L., Baumlein H. Gene regulation during late embryogenesis: the RY motif of maturation-specific gene promoter is a direct target of the FUS3 gene product. Plant J. 2000. Vol. 21. P. 401-408.

9. de Pater S., Katagiri F., Kijne J., Chua N.-H. bZIP proteins bind to a palindromic sequence without an ACGT core located in a seed-specific element of the pea lectin promoter. Plant J. 1994. Vol. 6. P. 133-140.

10. Lefevre J.-F., Lane A.N., Jardetzky O. A temperature dependent transition in the Pribnow box of the trp promoter. FEBS. 1985. Vol. 190. P. 37-40.

11. Chou K.-С., Kйzdy F.J., Reusser F. Kinetics of processive nucleic acid polymerases and nucleases. Anal. Biochem. 1994. Vol. 221. P. 217-230.

\section{КУРЧІЙ Б.О.}

Ірпінський економічний коледж,

Україна, 08200, м. Ірпінь, вул. Гагаріна, 9, е-таil: kurchii@ukr.net

\section{РОЛЬ БІОЛОГІЧНО АКТИВНИХ РЕЧОВИН ТА КОРОТКИХ АТ-ФРАГМЕНТІВ НУКЛЕЇНОВИХ КИСЛОТ У ПРОЦЕСІ ГЕНЕТИЧНОӦ ТРАНСКРИПЦЇ̈}

Описано специфічні фрагменти названих функціонально реактивними групами (або дескрипторами) в молекулах біологічно активних речовин (БАР). Ці фрагменти характеризуються наявністю активного атома водню або ненасиченою функцією. Зроблено висновок, що БАР $є$ найважливішими факторами, котрі співпрацюють 3 генетичними ключами та генетичними замками, щоб розпочати транскрипцію. Генетичні ключі - це нуклеїнові кислоти, але не білки. Постулюється, що клітинна мембрана може служити депо для генетичних ключів на початку окисного стресу. Під час фази рецесії окисного стресу синтезуються нові генні ключі для нових транскрипційних актів.

Ключові слова: БАР, дескриптори, генні ключі, генні замки, транскрипція. 